\title{
Effect of Azolla pinnata Use In Feed and Probiotics On Carcase Percentage and Fat Abdominal Broiler
}

\author{
by : \\ Nilawati \\ Lecturer of the State Agricultural Polytechnic Payakumbuh \\ State Highway KM.7 Tanjung Pati, District Harau Limapuluh Kota District \\ nilanilawati70@yahoo.com
}

\begin{abstract}
Livestock business is not separated from the cost of feeds issued. Feed is the largest production costs of $60-70 \%$ of the total production costs, so it needs to look for and utilize other alternative feed ingredients that do not compete with humans, the price is cheap, easy to obtain and not ignore the content nutrients from the feed ingredients.

One of the alternative feed ingredients derived from agricultural waste that is available in large quantities and can be used as animal feed is Azolla pinnata with crude protein content ranging from $24-30 \%$. Azolla pinnata plants or water spikes are the plants that usually live on the water surface, so far the farmers consider Azolla pinnata as a weed that disturbs their crops, so Azolla pinnata much thrown away by the farmers.

In addition to utilizing Azolla pinnata as broiler feed and broilernya optimal growth should be added probiotics. Provision of probiotics are expected to function to maintain the health of chicken digestion as well as a growth spur so that later available food poultry products in the form of good meat, healthy and reduce residual antibiotics.

This research has been conducted in Farm State Agricultural Polytechnic Payakumbuh. The data were collected for four weeks using 100 broiler children, with Completely Randomized Design using 5 treatments and 4 replications, with parameters: weight gain, consumption, conversion, carcass percentage and abdominal fat.

The results of this study show that there is an increase in body weight and percentage of carcass. The average percentage of carcasses ranged between $59.24 \%-67.52 \%$ and the abdominal fat percentage ranged from $9.86 \%$ to $11.34 \%$.

The conclusion of this study besides can reduce production cost also seen that best treatment that is combination in use of Azolla pinnata $15 \%$ and probiotic $10 \mathrm{ml}$.
\end{abstract}

Keywords: Azolla pinnata, probiotics, broiler, carcass, abdominal fat

\author{
ABSTRACT \\ Effect Of Azolla pinnata Use In Feed and Probiotics On Carcase Percentage \\ and Fat Abdominal Broiler
}

by : 


\author{
Nilawati \\ Lecturer of the State Agricultural Polytechnic Payakumbuh \\ nilanilawati70@yahoo.com
}

Usaha peternakan tidak lepas dari biaya pakan yang dikeluarkan.Pakan merupakan biaya produksi yang terbesar yaitu 60 - 70\% dari total biaya produksi, sehingga perlu dicari dan memanfaatkan bahan pakan alternatif lain yang tidak bersaing dengan manusia, harganya murah, mudah didapat dan tidak mengabaikan kandungan nutrisi dari bahan pakan tersebut.

Salah satu bahan pakan alternatif yang berasal dari limbah pertanian yang tersedia dalam jumlah banyak dan bisa dimanfaatkan sebagai bahan makanan ternak adalah Azolla pinnata dengan kandungan protein kasarnya berkisar antara $24-30 \%$. Tanaman Azolla pinnata atau paku air merupakan tanaman yang biasa hidup di atas permukaan air, Selama ini para petani menganggap Azolla pinnata sebagai gulma yang mengganggu tanaman pertanian mereka, sehingga Azolla pinnata banyak dibuang begitu saja oleh para petani.

Selain memanfaatkan Azolla pinnata sebagai pakan ternak broiler dan supaya pertumbuhan broilernya optimal perlu ditambahkan probiotik. Pemberian probiotik diharapkan berfungsi menjaga kesehatan pencernaan ayam disamping sebagai pemacu pertumbuhan sehingga nantinya tersedia pangan produk unggas berupa daging yang baik, sehat dan mengurangi residu antibiotik.

Penelitian ini telah dilaksanakan di Farm Politeknik Pertanian Negeri Payakumbuh. Pengambilan data ini selama 28 hari yang menggunakan 100 ekor anak broiler, dengan Rancangan Acak Lengkap yang menggunakan 5 perlakuan dan 4 ulangan, dengan parameter yaitu pertambahan berat badan, konsumsi, konversi, persentase karkas dan lemak abdominal.

Hasil penelitian ini terlihat bahwa terjadi peningkatan berat badan dan persentase karkas . Rata rata persenatse karkas berkisar antara 59,24\% - 67,52\% dan dan persentase lemak abdominal berkisar antara $9.86 \%-11,34 \%$.

Kesimpulan dari penelitian ini selain bisa menekan biaya produksi juga terlihat bahwa perlakuan yang terbaik yaitu kombinasi dalam penggunaan Azolla pinnata $15 \%$ dan probiotik $10 \mathrm{ml}$.

Kata Kunci : Azolla pinnata, probiotik, broiler, karkas, lemak abdominal 